\title{
Using Electrospray Ionization Mass Spectrometry to Explore the Interactions Among Polythymine Oligonucleotides, Ethidium Bromide, and Mercury Ions
}

\author{
Cheng-Kang Chiang, ${ }^{a}$ Yang-Wei Lin, ${ }^{a}$ Cho-Chun Hu, \\ and Huan-Tsung Chang ${ }^{\mathrm{a}}$ \\ ${ }^{a}$ Department of Chemistry, National Taiwan University, Taipei, Taiwan \\ b Department of Applied Science, National Taitung University, Taitung, Taiwan
}

We have used electrospray ionization mass spectrometry (ESI-MS) and fluorescence and circular dichroism (CD) spectroscopy to explore the binding of ethidium bromide (EthBr) to non-self-complementary polythymine (polyT) strands in the absence and presence of $\mathrm{Hg}^{2+}$ ions. In the gas phase, ESI-MS revealed that $\mathrm{Hg}^{2+}$ ions have greater affinity, through $\mathrm{T}-\mathrm{Hg}^{2+}-\mathrm{T}$ coordination, toward polyT strands than do other metal ions. These findings are consistent with our fluorescence and $\mathrm{CD}$ results obtained in solution; they revealed that more $\mathrm{T}_{33}-\mathrm{EthBr}-\mathrm{Hg}^{2+}$ complexes existed upon increasing the concentrations of $\mathrm{Hg}^{2+}$ ions (from 0 to $50 \mu \mathrm{M}$ ). Surprisingly, the ESI-MS data indicated that the $\mathrm{Hg}^{2+}$ concentration dependence of the interaction between $\mathrm{T}_{33}$ and EthBr is biphasic. Our ESI-MS data revealed that the $\mathrm{T}_{33}-\mathrm{EthBr}-\mathrm{Hg}^{2+}$ complexes formed with various stoichiometries depending on their relative concentrations of the components and the length of the DNA strand. When the concentrations of $\mathrm{T}_{33} / \mathrm{EthBr} / \mathrm{Hg}^{2+}$ were $5 / 5 / 2.5 \mu \mathrm{M}$ and $5 / 10 / 7.5 \mu \mathrm{M}, 1: 1: 1$ and 1:1:2 $\mathrm{T}_{33}-\mathrm{EthBr}-\mathrm{Hg}^{2+}$ complexes were predominantly formed, respectively. Thus, $\mathrm{Hg}^{2+}-$ induced DNA conformational changes clearly affect the interactions between DNA and EthBr. (J Am Soc Mass Spectrom 2009, 20, 1834-1840) (c) 2009 American Society for Mass Spectrometry

S tudies of the interactions between $\mathrm{Hg}^{2+}$ ions and DNA are interesting because they affect many different areas of the brain and their associated functions, resulting in symptoms such as vision problems, deafness, and loss of muscle coordination [1]. It has long been known that $\mathrm{Hg}^{2+}$ ions interact strongly with DNA strands through thymine $(\mathrm{T})-\mathrm{Hg}^{2+}-\mathrm{T}$ coordination [2]; indeed, taking advantage of such complexation allows the detection of $\mathrm{Hg}^{2+}$ ions through $\mathrm{Hg}^{2+}$-induced conformational changes of DNA [3-5]. Recently, we presented a simple and rapid fluorescence assay, using the double-stranded DNA binding dye TOTO-3 and the polythymine oligonucleotide $\mathrm{T}_{33}$, for the highly selective and sensitive detection of $\mathrm{Hg}^{2+}$ in aqueous solution [6]. In the presence of $\mathrm{Hg}^{2+}$ ions, $\mathrm{T}_{33}$ changes its conformation from a random coil to a hairpin-like structure, leading to increased fluorescence. The formation of $\mathrm{T}-\mathrm{Hg}^{2+}-\mathrm{T}$ complexes has been confirmed indirectly using fluorescence polarization spectroscopy, capillary electrophoresis (CE), circular dichroism (CD) spectroscopy, and melting temperature

Address reprint requests to Dr. H.-T. Chang, Department of Chemistry, National Taiwan University, 1, Section 4, Roosevelt Road, Taipei 106, Taiwan. E-mail: changht@ntu.edu.tw measurements [3-6]. At this time, no direct evidence of such interactions exist.

Electrospray ionization mass spectrometry (ESI-MS) has been used to investigate the interactions of small analytes with various types of DNA structures, including G-quadruplexes [7-11] and DNA duplexes [12-16]. For example, ESI-MS has provided evidence for the existence of interactions between perylene diimides and G-quadruplex DNA [17], ethidium bromide (EthBr) and DNA duplexes [18], and metal ions and single-/doublestranded DNA [19-22]. ESI-MS allows the transfer of noncovalently bound complexes in solution to the gas phase without disruption of the complexes [23]. Thus, ESI-MS techniques are powerful for obtaining biomolecular structures and for determining the concentrations of all species of interest.

In this study, we used fluorescence and CD spectroscopy and ESI-MS to investigate the interactions between polyT strands and $\mathrm{Hg}^{2+}$ ions in the absence and presence of EthBr. EthBr has been used widely in CE-based analyses of DNA [24-26]. In addition, it has been established that EthBr interacts with DNA triplexes and G-quadruplexes [9]. In this study, we investigated the roles played by the concentrations of $\mathrm{Hg}^{2+}$ and EthBr, the length of DNA, and the DNA: $\mathrm{Hg}^{2+}$ : 
EthBr molar ratio in determining the interactions among DNA, $\mathrm{Hg}^{2+}$, and EthBr.

\section{Experimental}

\section{Chemicals}

Ammonium acetate $\left(\mathrm{NH}_{4} \mathrm{OAc}\right)$, metal ions (all nitrate salts), and other reagents were purchased from Aldrich (Milwaukee, WI, USA). EthBr was obtained from Pharmacia Biotech (Uppsala, Sweden). PolyTs $\left(T_{7}, T_{15}, T_{33}\right.$, and $\mathrm{T}_{50}$ ) were purchased from Integrated DNA Technology (Coralville, IA, USA).

\section{ESI-MS}

A Bruker esquire HCT mass spectrometer (Bremen, Germany) was operated in the negative mode with a capillary voltage of $2.5 \mathrm{kV}$; the dry gas flow rate was controlled at $3.0 \mathrm{~L} / \mathrm{min}$; the nebulizer was controlled at $13.0 \mathrm{psi}$, and dry temperature was set to $250{ }^{\circ} \mathrm{C}$. Full scan MS spectra were recorded in the $m / z$ range $250-$ 1500 with 50 acquisitions per spectrum. To obtain stable electrospray signals, $20 \% \mathrm{MeOH}$ was added to each of the injected solutions before ESI-MS measurement. Aliquots $(10 \mu \mathrm{L})$ of metal ion solutions $(10-500 \mu \mathrm{M})$ were added separately to $\mathrm{NH}_{4} \mathrm{OAc}$ solutions (5 mM, pH 7.0, $0.1 \mathrm{~mL}$ ), each containing one of the polyT oligonucleotides $(5 \mu \mathrm{M})$ and EthBr $(0-20 \mu \mathrm{M})$. The mixtures were equilibrated at ambient temperature for $30 \mathrm{~min}$. The DNA samples were infused directly at $3 \mu \mathrm{L} / \mathrm{min}$ into the mass spectrometer.

We calculated the fraction of $\mathrm{T}_{33}-\mathrm{Hg}^{2+}$ complexes using eq 1 according to a reported method [17]

Fraction of $\mathrm{T}_{33}-\mathrm{Hg}^{2+}$ complexes

$$
=\frac{I_{(1: 1)}+I_{(1: 2)}+I_{(1: 3)}+\ldots+I_{(1: n)}}{I_{T_{33}}+I_{(1: 1)}+I_{(1: 2)}+I_{(1: 3)}+\ldots+I_{(1: n)}}
$$

where $I_{\mathrm{T} 33}$ and $I_{(1: n)}$ represent the intensity of $\mathrm{T}_{33}$ and $\mathrm{T}_{33}-n \mathrm{Hg}^{2+}$ complex, respectively, $n$ is integral.

\section{Spectroscopy}

Samples $(1.0 \mathrm{~mL})$ containing $\mathrm{T}_{33}(1 \mu \mathrm{M}), \mathrm{Hg}^{2+}(0-5$ $\mu \mathrm{M})$, EthBr (0-5 $\mu \mathrm{M})$, and $\mathrm{NH}_{4} \mathrm{OAc}(5 \mathrm{mM}, \mathrm{pH} 7.0)$ in the presence of $20 \% \mathrm{MeOH}$ were equilibrated at room temperature for $30 \mathrm{~min}$ before $\mathrm{CD}$ measurements. CD spectra of these mixtures were recorded in the wavelength range 240-320 $\mathrm{nm}$ using a J-815 CD spectropolarimeter (JASCO, Easton, MD, USA). A quartz cell (ChromTech $\mathrm{GmbH}$, Idstein, Germany) having a path length of $1 \mathrm{~cm}$ was used as the sample vial to obtain the CD spectra, recorded from 240 to $320 \mathrm{~nm}$ at $0.1 \mathrm{~nm}$ intervals.

\section{Fluorescence Spectroscopy}

A Cary Eclipse fluorescence spectrophotometer (Varian, Palo Alto, CA, USA) was used to record the fluorescence spectra of mixtures similar to those used for the CD spectroscopy measurements. The fluorescence intensities of mixtures containing $\mathrm{T}_{33}(1 \mu \mathrm{M})$ and EthBr $(1$ $\mu \mathrm{M})$ in the absence and presence of $\mathrm{Hg}^{2+}(0-50 \mu \mathrm{M})$ at $610 \mathrm{~nm}$ were recorded when excited at $530 \mathrm{~nm}$. The Job method of continuous variation was used to determine the stoichiometries of the $\mathrm{T}_{33}-\mathrm{EthBr}-\mathrm{Hg}^{2+}$ complexes in the presence of $\mathrm{Hg}^{2+}(0-50 \mu \mathrm{M})$. To determine the stoichiometries of the complexes, the molar fraction of $\operatorname{EthBr}\left(X_{\mathrm{EthBr}}\right)$ was varied, while the total concentration of EthBr and $\mathrm{T}_{33}$ was maintained at $1 \mu \mathrm{M}$.

\section{Results and Discussion}

ESI-MS of $T_{33}$

Figure 1a displays the mass spectrum of a solution of $\mathrm{T}_{33}(5 \mu \mathrm{M})$ in the presence of $20 \% \mathrm{MeOH}$. We assign the signals at $m / z$ 906.0, 830.4, 766.4, 711.6, 664.1, and 622.5 to the ions $\left[\mathrm{T}_{33}-11 \mathrm{H}^{+}\right]^{11-},\left[\mathrm{T}_{33}-12 \mathrm{H}^{+}\right]^{12-},\left[\mathrm{T}_{33}-\right.$ $\left.13 \mathrm{H}^{+}\right]^{13-},\left[\mathrm{T}_{33}-14 \mathrm{H}^{+}\right]^{14-},\left[\mathrm{T}_{33}-15 \mathrm{H}^{+}\right]^{15-}$, and $\left[\mathrm{T}_{33}-\right.$ $\left.16 \mathrm{H}^{+}\right]^{16-}$, respectively. The broadness of most of these peaks results mainly from the counterion condensation of $\mathrm{T}_{33}$ during droplet evaporation and the formation of $\mathrm{Na}^{+}$and/or $\mathrm{K}^{+}$adducts of $\mathrm{T}_{33}[7,27]$. Upon increasing the $\mathrm{NH}_{4} \mathrm{OAc}$ concentration to $5 \mathrm{mM}$ (Figure $1 \mathrm{~b}$ ), the most abundant signals were those of the $\left[\mathrm{T}_{33}-\right.$ $\left.13 \mathrm{H}^{+}\right]^{13-}$, with good mass spectra sensitivity. The interfering peaks at $m / z$ 556.1, 680.6, and 980.0 are assigned to the $\left[7 \mathrm{NH}_{4} \mathrm{OAc}+\mathrm{H}_{2} \mathrm{O}-\mathrm{H}^{+}\right]^{-},\left[17 \mathrm{NH}_{4} \mathrm{OAc}+\right.$ $\left.3 \mathrm{H}_{2} \mathrm{O}-2 \mathrm{H}^{+}\right]^{2-}$, and $\left[25 \mathrm{NH}_{4} \mathrm{OAc}+2 \mathrm{H}_{2} \mathrm{O}-2 \mathrm{H}^{+}\right]^{2-}$, respectively. Upon further increasing $\mathrm{NH}_{4} \mathrm{OAc}$ concentration (Figure 1c; $50 \mathrm{mM} \mathrm{NH}_{4} \mathrm{OAc}$ ), the analyte ionization was suppressed. Thus, the optimal concentration of $\mathrm{NH}_{4} \mathrm{OAc}$ was chosen at $5 \mathrm{mM}$ for further ESI-MS measurements.

\section{Interactions Between $T_{33}$ and Metal Ions}

Figure 2a displays the ESI-MS spectrum of $\mathrm{T}_{33}(5.0 \mu \mathrm{M})$ recorded in the presence of $1 \mu \mathrm{M} \mathrm{Hg}^{2+}$ ions; we assign the peak appearing at $\mathrm{m} / \mathrm{z} 781.7$ to the $\left[\mathrm{T}_{33}+\mathrm{Hg}^{2+}{ }_{-}\right.$ $\left.15 \mathrm{H}^{+}\right]^{13-}$ ion. Upon increasing the concentration of $\mathrm{Hg}^{2+}$, the intensity of this peak increased. For example, Using eq 1, we calculated the fraction of the intensity of the signal for the $\left[\mathrm{T}_{33}+\mathrm{Hg}^{2+}-15 \mathrm{H}^{+}\right]^{13-}$ ion to the total intensity of the signals for $T_{33}$ species (i.e., $\left[\mathrm{T}_{33}-\right.$ $\left.\left.13 \mathrm{H}^{+}\right]^{13-}+\left[\mathrm{T}_{33}+\mathrm{Hg}^{2+}-15 \mathrm{H}^{+}\right]^{13-}\right)$. The fraction increased from $11 \%$ to $20 \%$ upon increasing the concentration of $\mathrm{Hg}^{2+}$ from 1.0 to $5.0 \mu \mathrm{M}$ (Figure $2 \mathrm{~b}$ ). Figure 2c reveals that increasing the concentration of $\mathrm{Hg}^{2+}$ ions to $10.0 \mu \mathrm{M}$ caused the fractional intensity of the signal for the $\left[\mathrm{T}_{33}+\mathrm{Hg}^{2+}-15 \mathrm{H}^{+}\right]^{13-}$ ions to increase to $23 \%$. In addition, a peak representing the $\left[\mathrm{T}_{33}+2 \mathrm{Hg}^{2+}-\right.$ $\left.17 \mathrm{H}^{+}\right]^{13-}$ ion appeared (fractional intensity: $8 \%$ ). At 


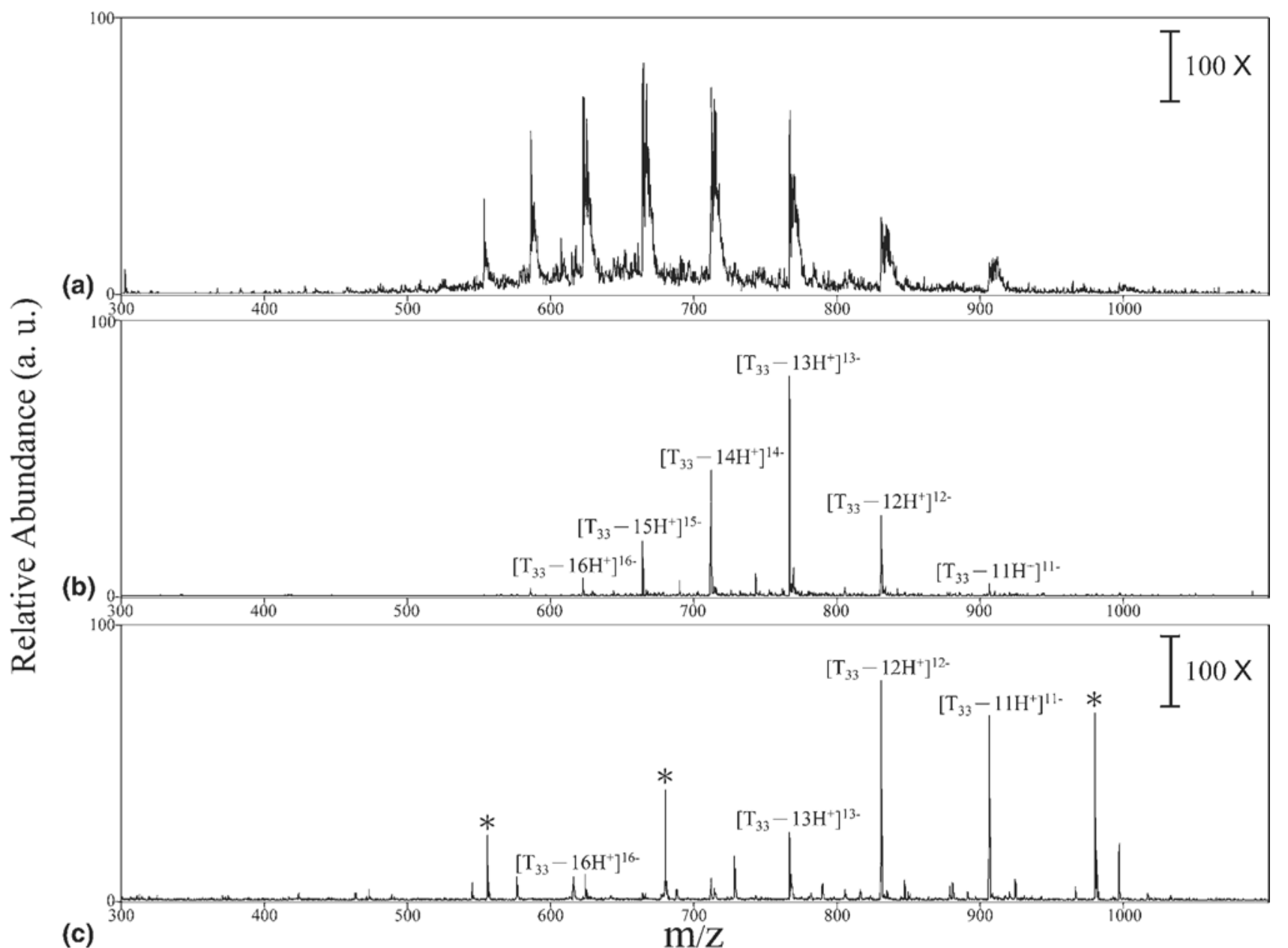

Figure 1. ESI-MS spectra of (a) $\mathrm{T}_{33}(5 \mu \mathrm{M})$ in a solution containing $20 \% \mathrm{MeOH}$ and (b), (c) $\mathrm{T}_{33}(5 \mu \mathrm{M})$ in solutions containing $20 \% \mathrm{MeOH}$ and (b) $5 \mathrm{mM}$ and (c) $50 \mathrm{mM} \mathrm{NH}_{4} \mathrm{OAc}$ (pH 7.0). The mass spectral intensities are plotted in arbitrary units (a.u.). The asterisks at $m / z 556.1,680.1$, and 980.0 denote blank peaks that are also present in the spectrum of $50 \mathrm{mM} \mathrm{NH}_{4} \mathrm{OAc}$ containing $20 \% \mathrm{MeOH}$.

$50.0 \mu \mathrm{M} \mathrm{Hg}^{2+}$ ions, we obtained the maximum number of five $\mathrm{Hg}^{2+}$ ions bound onto $\mathrm{T}_{33}$, i.e., the $\left[\mathrm{T}_{33}+5 \mathrm{Hg}^{2+}-\right.$ $\left.23 \mathrm{H}^{+}\right]^{13-}$ ion (Figure $2 \mathrm{~d}$ ). The mass resolution and peak intensity both decreased when the concentration of $\mathrm{Hg}^{2+}$ ions was greater than $50.0 \mu \mathrm{M}$.

\section{Interaction Between $T_{33}$ and Other Metal Ions}

Electrostatic interactions between the DNA phosphate backbone and metal ions can alter the conformation and ionization efficiency of DNA [19]. We conducted ESI-MS measurements to investigate the interactions between $\mathrm{T}_{33}$ and various other metal ions, including $\mathrm{Pb}^{2+}, \mathrm{Ag}^{+}, \mathrm{Fe}^{3+}, \mathrm{Cr}^{3+}, \mathrm{Ni}^{2+}, \mathrm{Cu}^{2+}, \mathrm{Co}^{2+}, \mathrm{Zn}^{2+}$, and $\mathrm{Cd}^{2+}$, at concentrations ranging from 5 to $50 \mu \mathrm{M}$. Figure 3 reveals that the fraction of $\mathrm{T}_{33}$ toward $\mathrm{Hg}^{2+}$ ions is higher than those of the other metal ions. In a previous study using fluorescence spectroscopy, we found that the fluorescence intensity of the TOTO- $3 \cdot \mathrm{T}_{33}$ complex was enhanced 265-fold for $\mathrm{Hg}^{2+}$ over those of the other metal ions [6]. We note that different buffers (Tris- $\mathrm{HCl}$ and $\mathrm{NH}_{4} \mathrm{OAc} / \mathrm{MeOH}$ ) and phases (liquid and gas) were used in the two cases, leading to different selectivity values.

Effects of polyT Lengths in the Presence of Various $\mathrm{Hg}^{2+}$ or EthBr Concentrations

We investigated the impact of the length of the polyT on the interactions of DNA with $\mathrm{Hg}^{2+}$ ions and with EthBr molecules by using $T_{7}, T_{15}$, and $T_{50}$ as additional DNA strands, respectively. To maintain the same number of $\mathrm{T}$ bases as that of $\mathrm{T}_{33}(5 \mu \mathrm{M})$, we set the concentrations of $\mathrm{T}_{7}, \mathrm{~T}_{15}$, and $\mathrm{T}_{50}$, at $23.5,11$, and $3.3 \mu \mathrm{M}$, respectively. As expected, the interactions of DNA with $\mathrm{Hg}^{2+}$ increased upon increasing the length of the polyT strand (Fig. S1, which can be found in the electronic version of this article). Similar to the behavior of $\mathrm{T}_{33}$, the binding of the other three polyTs all exhibited a dependence on the $\mathrm{Hg}^{2+}$ concentration. Of the four tested polyTs, the interactions of $\mathrm{T}_{7}$ with $\mathrm{Hg}^{2+}$ ions were the weakest, mainly due to its difficulty of forming a hairpin-like structure and its lower number of T units [6]. Figure S2 


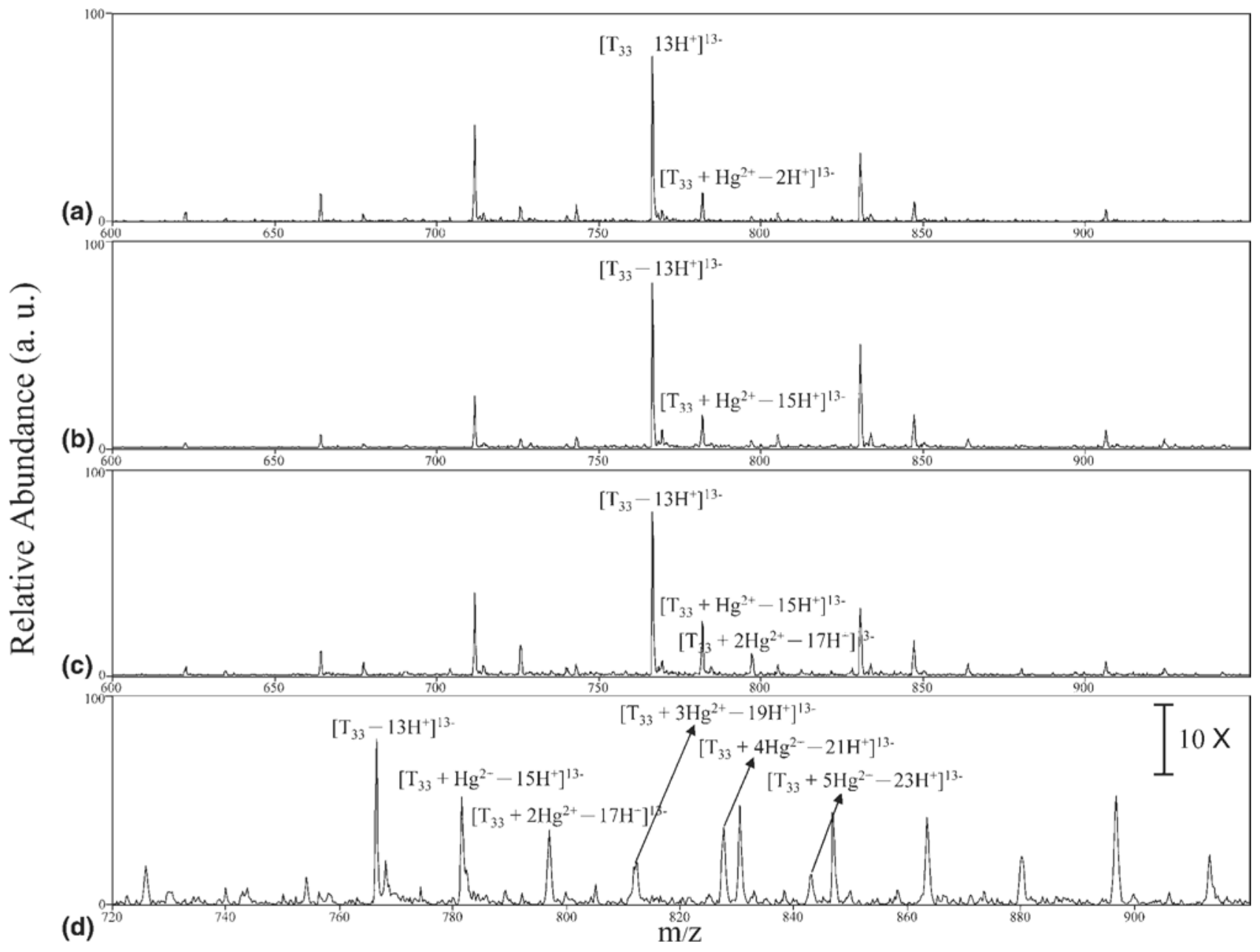

Figure 2. ESI-MS spectra of solutions containing $\mathrm{T}_{33}(5 \mu \mathrm{M}), 20 \% \mathrm{MeOH}, 5 \mathrm{mM} \mathrm{NH}_{4} \mathrm{OAc}$, and $\mathrm{Hg}^{2+}$ ions at concentrations of (a) 1, (b) 5, (c) 10, and (d) $50 \mu \mathrm{M}$. Other conditions were the same as those described in Figure 1.

reveals that the strengths of the interactions of the four polyT strands with EthBr increased upon increasing EthBr concentration $(0-20 \mu \mathrm{M})$; the interaction strengths decreased in the order $\mathrm{T}_{50}>\mathrm{T}_{33}>\mathrm{T}_{15}>\mathrm{T}_{7}$.

\section{Interactions Among PolyT Strands, $\mathrm{Hg}^{2+}$ Ions,} and $\mathrm{EthBr}$

In the solutions composed of polyTs, $\mathrm{EtBr}(5.0 \mu \mathrm{M})$, and various $\mathrm{Hg}^{2+}$ concentrations $(0-20.0 \mu \mathrm{M})$, several complexes were formed, including $\left[\mathrm{T}_{33}+n\right.$ Ethidium $-(13+$ n) $\left.\mathrm{H}^{+}\right]^{13-},\left[\mathrm{T}_{33}+m \mathrm{Hg}^{2+}-(13+2 m) \mathrm{H}^{+}\right]^{13-}$, and $\left[\mathrm{T}_{33}+\right.$ $n$ Ethidium $\left.+m \mathrm{Hg}^{2+}-(13+2 m+n) \mathrm{H}^{+}\right]^{13-}$, where $m$ and $n$ are integral, respectively). Upon increasing the $\mathrm{Hg}^{2+}$ concentration, the fraction of the polyT-EthBr complexes decreased, whereas those for the polyT$\mathrm{Hg}^{2+}$ complexes increased (Figure 4.) PolyT-EthBr$\mathrm{Hg}^{2+}$ complexes having binding stoichiometries of 1:1:1 occurred for the $\mathrm{T}_{15}, \mathrm{~T}_{33}$, and $\mathrm{T}_{50}$ systems at $\mathrm{Hg}^{2+}$ concentrations of $2.5 \mu \mathrm{M}$; for the $\mathrm{T}_{7}$-containing system, however, the 1:1:1 complexes occurred only at $20.0 \mu \mathrm{M}$ $\mathrm{Hg}^{2+}$. At this concentration of $\mathrm{Hg}^{2+}$ ions, 1:1:2 polyT-
EthBr- $\mathrm{Hg}^{2+}$ complexes formed for the $\mathrm{T}_{33}$ and $\mathrm{T}_{50}$ systems. Figure $\mathrm{S} 3$ displays peaks at $\mathrm{m} / \mathrm{z} 805.8$ and 821.0 for the $\left[\mathrm{T}_{33}+\mathrm{Hg}^{2+}+\text { Ethidium }-16 \mathrm{H}^{+}\right]^{13-}$ and $\left[\mathrm{T}_{33}+\right.$

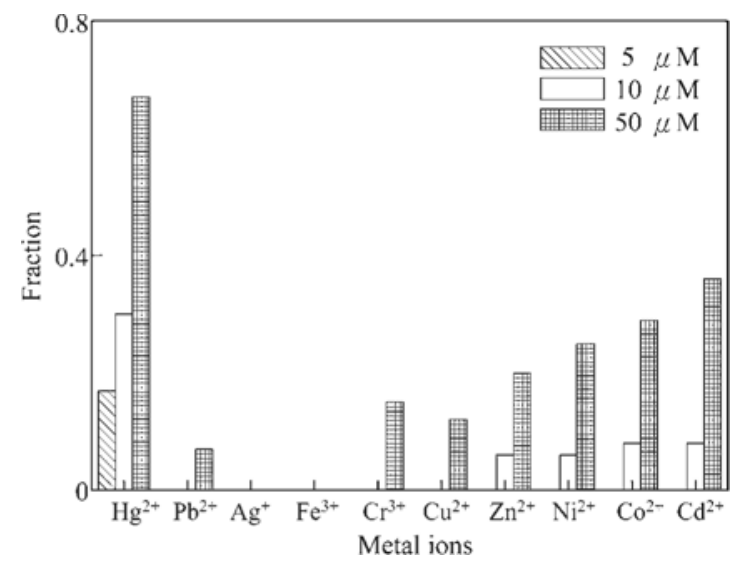

Figure 3. Fractions of $\mathrm{T}_{33}$-metal ion complexes in solutions containing $\mathrm{T}_{33}(5 \mu \mathrm{M})$ and metal ions $(5-50 \mu \mathrm{M})$. Other conditions were the same as those described in Figure 1. 

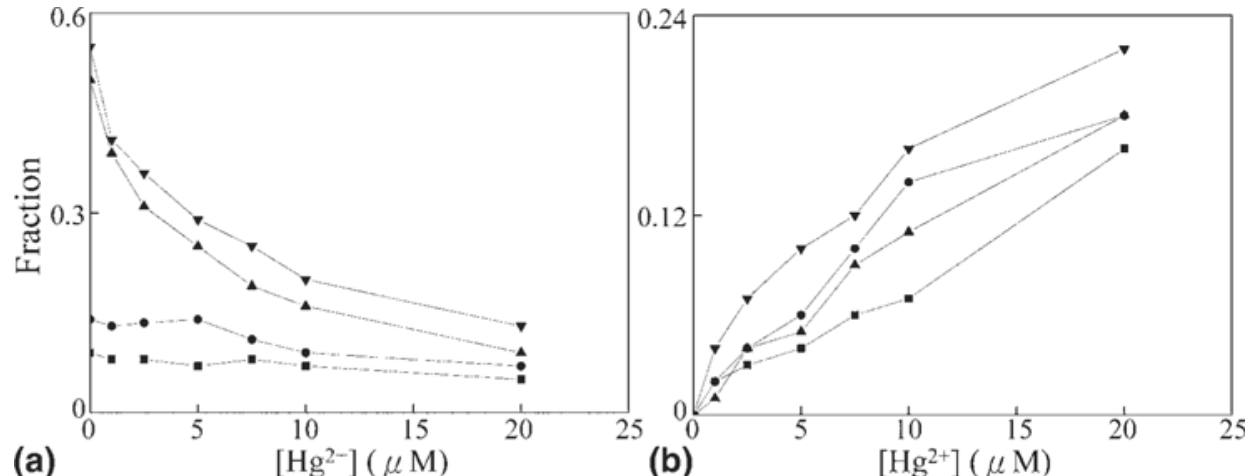

Figure 4. Fractions of (a) $\mathrm{T}_{33}-\mathrm{EthBr}$ and (b) $\mathrm{T}_{33}-\mathrm{Hg}^{2+}$ complexes in solutions containing polyT strands, EthBr $(5 \mu \mathrm{M})$, and $\mathrm{Hg}^{2+}$ ions $(0-20 \mu \mathrm{M})$, determined using ESI-MS. [filled square]: $\mathrm{T}_{7}(23.5$ $\mu \mathrm{M})$; [filled circle]: $\mathrm{T}_{15}(11 \mu \mathrm{M})$; [filled triangle]: $\mathrm{T}_{33}(5 \mu \mathrm{M})$; [inverted filled triangle]: $\mathrm{T}_{50}(3.3 \mu \mathrm{M})$. Other conditions were the same as those described in Figure 1.

$2 \mathrm{Hg}^{2+}+$ Ethidium $\left.-18 \mathrm{H}^{+}\right]^{13-}$, respectively, showing the existence of $\mathrm{T}_{33}-\mathrm{EthBr}-\mathrm{Hg}^{2+}$ complexes. These peaks signals increased upon increasing $\mathrm{Hg}^{2+}$ concentration $(2.5-5.0 \mu \mathrm{M})$. Table 1 summarizes the effects of the $\mathrm{Hg}^{2+}$ and EthBr concentrations on the formation of the $\mathrm{T}_{33}-\mathrm{EthBr}, \mathrm{T}_{33}-\mathrm{Hg}^{2+}$, and $\mathrm{T}_{33}-\mathrm{EthBr}-\mathrm{Hg}^{2+}$ complexes. Greater concentrations of $\mathrm{Hg}^{2+}$ ions were required to form $\mathrm{T}_{33}-\mathrm{EthBr}-\mathrm{Hg}^{2+}$ complexes at higher EthBr concentrations. These results suggest that electrostatic interactions, but not intercalations, were the major forces between the EthBr molecules and the polyT strands. Upon increasing the concentration of $\mathrm{Hg}^{2+}$ ions in the polyT-EthBr- $\mathrm{Hg}^{2+}$ systems, the negative charge density of the DNA strands decreased, leading to their decreased interactions with EthBr.

Next, we examined the interactions of $\mathrm{T}_{33}$ with $\mathrm{EthBr}$ and $\mathrm{Hg}^{2+}$ ions in aqueous solution using fluorescence and $\mathrm{CD}$ spectroscopy. To minimize their consumption, we maintained the concentrations of both $\mathrm{T}_{33}$ and $\mathrm{EthBr}$ at $1.0 \mu \mathrm{M}$. Figure 5 a displays the values of $\left(I_{\mathrm{F}}-I_{\mathrm{FO}}\right) / I_{\mathrm{FO}}$ for the $\mathrm{T}_{33}-\mathrm{EthBr}$ and $\mathrm{T}_{33}-\mathrm{EthBr}-\mathrm{Hg}^{2+}$ complexes at $\mathrm{Hg}^{2+}$ concentrations ranging from 0 to $50.0 \mu \mathrm{M}$, where $I_{\mathrm{FO}}$ and $I_{\mathrm{F}}$ represent the fluorescence intensities of the $\mathrm{T}_{33}-\mathrm{EthBr}$ and $\mathrm{T}_{33}-\mathrm{EthBr}-\mathrm{Hg}^{2+}$ complexes, respec- tively. The fluorescence intensity of the solutions increased upon increasing the $\mathrm{Hg}^{2+}$ concentration in the range of $0-10.0 \mu \mathrm{M}$, while decreased in the range of 10.0-20.0 $\mu \mathrm{M}$. At the low $\mathrm{Hg}^{2+}$ concentration, the fluorescence increase arose mainly from (1) the greater number of EthBr molecules intercalated with $\mathrm{T}_{33}$ as a result of the formation of a hairpin-like $\mathrm{T}_{33}$ structures, and (2) the increase in the quantum yield of the $\mathrm{T}_{33}$ EthBr complexes when their structure became more rigid. In contrast, electrostatic repulsion disrupted the interactions between $\mathrm{T}_{33}$ and $\mathrm{EthBr}$ at high $\mathrm{Hg}^{2+}$ concentrations. Figure S4 displays that the fluorescence intensities of the solution composed of $\mathrm{T}_{33}, \mathrm{EthBr}$, and $\mathrm{Hg}^{2+}$ without/with conducting an annealing process were almost the same, showing that the temperature impact on the formation of the $\mathrm{T}_{33}-\mathrm{EthBr}-\mathrm{Hg}^{2+}$ complexes could be neglected. Figure $5 b$ presents Job plots derived from solutions containing constant total concentrations of $\mathrm{T}_{33}$ and EthBr and various $\mathrm{Hg}^{2+}$ concentrations, suggesting that the $\mathrm{T}_{33}-\mathrm{EthBr}$ complexes had approximate stoichiometries $\left(\mathrm{T}_{33}: \mathrm{EthBr}\right)$ of $1: 4,1: 2$, and 2:1 at 1.0, 10.0, and $20.0 \mu \mathrm{M} \mathrm{Hg}^{2+}$, respectively. These trends agree with our ESI-MS data (Table 1): upon increasing the $\mathrm{Hg}^{2+}$ ion concentrations, fewer EthBr

Table 1. Fractions of individual species in mixtures of $\mathrm{T}_{33}, \mathrm{EthBr}$, and $\mathrm{Hg}^{2+}$, determined using ESI-MS

\begin{tabular}{|c|c|c|c|c|c|}
\hline \multirow[b]{2}{*}{ Species } & \multicolumn{5}{|c|}{$\left[\mathrm{Hg}^{2+}\right](\mu \mathrm{M})$} \\
\hline & 0 & 1 & 5 & 10 & 20 \\
\hline$\left[\mathrm{T}_{33}+\mathrm{EthBr}\right]^{\mathrm{b}}$ & $0.50( \pm 0.03)^{d}$ & $0.40( \pm 0.01)$ & $0.25( \pm 0.01)$ & $0.16( \pm 0.01)$ & $0.09( \pm 0.007)$ \\
\hline$\left[\mathrm{T}_{33}+\mathrm{Hg}^{2+}\right]^{\mathrm{b}}$ & N.D. ${ }^{\mathrm{e}}$ & $0.01( \pm 0.001)$ & $0.05( \pm 0.01)$ & $0.11( \pm 0.01)$ & $0.18( \pm 0.01)$ \\
\hline$\left[\mathrm{T}_{33}+\mathrm{EthBr}+\mathrm{Hg}^{2+}\right]^{\mathrm{b}}$ & N.D. & N.D. & $0.06( \pm 0.01)$ & $0.07( \pm 0.003)$ & $0.07( \pm 0.004)$ \\
\hline$\left[\mathrm{T}_{33}+\mathrm{EthBr}+2 \mathrm{Hg}^{2+}\right]^{\mathrm{b}}$ & N.D. & N.D. & $0.02( \pm 0.002)$ & $0.02( \pm 0.001)$ & $0.02( \pm 0.001)$ \\
\hline$\left[\mathrm{T}_{33}+\mathrm{EthBr}\right]^{\mathrm{c}}$ & $1.00( \pm 0.04)$ & $0.87( \pm 0.03)$ & $0.62( \pm 0.03)$ & $0.40( \pm 0.03)$ & $0.18( \pm 0.02)$ \\
\hline$\left[\mathrm{T}_{33}+\mathrm{Hg}^{2+}\right]^{\mathrm{c}}$ & N.D. & N.D. & $0.02( \pm 0.001)$ & $0.03( \pm 0.002)$ & $0.05( \pm 0.02)$ \\
\hline$\left[\mathrm{T}_{33}+\mathrm{EthBr}+\mathrm{Hg}^{2+}\right]^{\mathrm{c}}$ & N.D. & N.D. & N.D. & $0.06( \pm 0.003)$ & $0.06( \pm 0.004)$ \\
\hline$\left[\mathrm{T}_{33}^{\infty}+\mathrm{EthBr}+2 \mathrm{Hg}^{2+}\right]^{\mathrm{c}}$ & N.D. & N.D. & N.D. & $0.02( \pm 0.001)$ & $0.02( \pm 0.002)$ \\
\hline
\end{tabular}

${ }^{a}$ All $\mathrm{T}_{33}(5 \mu \mathrm{M})$ samples were prepared in solutions containing $5 \mathrm{mM} \mathrm{NH}_{4} \mathrm{OAc}$ and $20 \% \mathrm{MeOH}$ (vol/vol).

$\mathrm{b}[\mathrm{EthBr}]=5 \mu \mathrm{M}$.

${ }^{\mathrm{c}}[\mathrm{EthBr}]=10 \mu \mathrm{M}$.

dValue is in five replicate measurements.

eN.D. = not detected in the mass spectrum. 


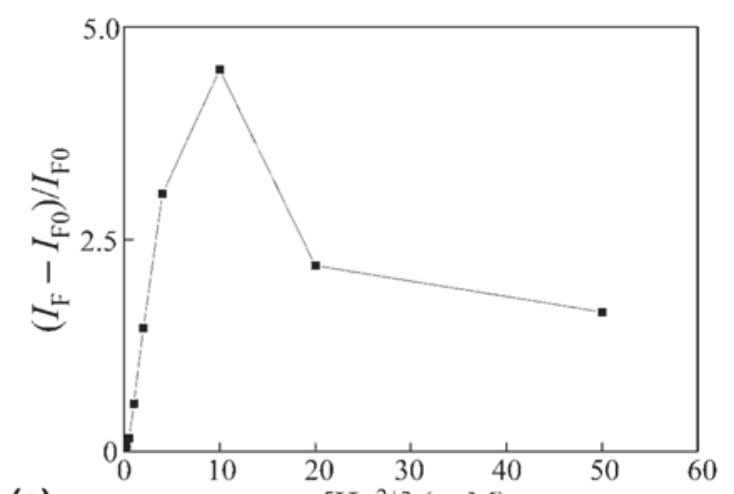

(a)
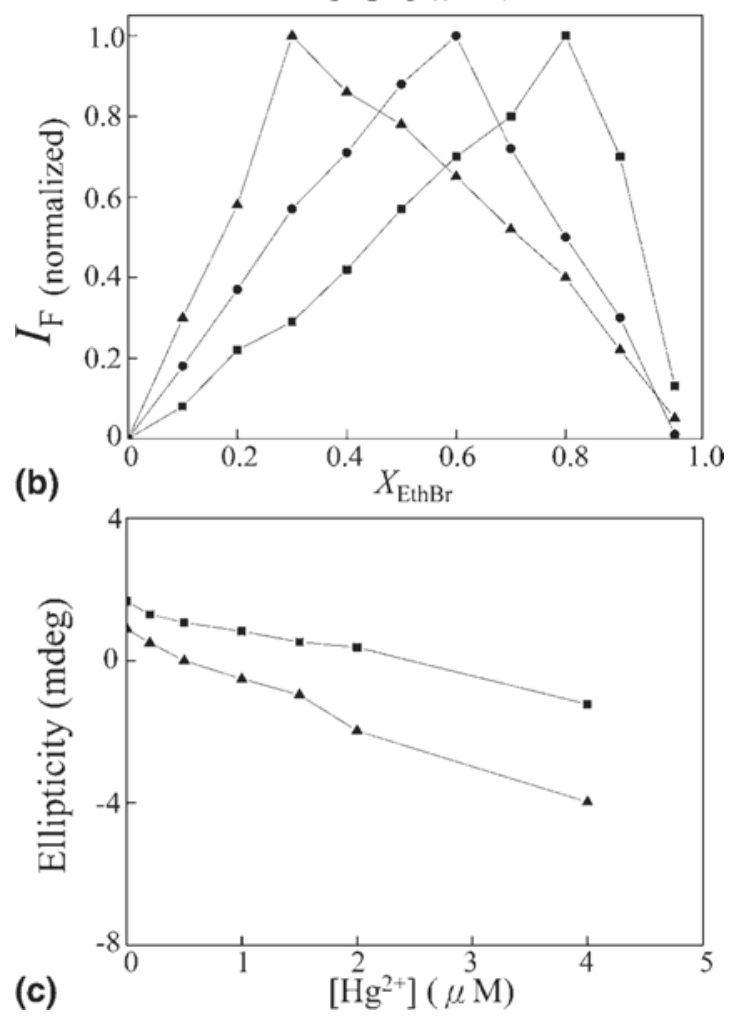

Figure 5. (a) Values of relative fluorescence $\left[\left(I_{\mathrm{F}}-I_{\mathrm{FO}}\right) / I_{\mathrm{FO}}\right]$ of solutions containing $\mathrm{T}_{33}(1 \mu \mathrm{M})$, EthBr $(1 \mu \mathrm{M})$, and $\mathrm{Hg}^{2+}$ ions $(0-50 \mu \mathrm{M})$. The samples were prepared in $5 \mathrm{mM} \mathrm{NH}_{4} \mathrm{OAc}(\mathrm{pH} 7.0)$ containing $20 \% \mathrm{MeOH}$; excitation wavelength: $530 \mathrm{~nm}$. The fluorescence intensities $\left(I_{\mathrm{F}}\right)$ at $610 \mathrm{~nm}$ are plotted in arbitrary units (a.u.). (b) Job plot for EthBr binding to $\mathrm{T}_{33}\left([\mathrm{EthBr}]+\left[\mathrm{T}_{33}\right]=1 \mu \mathrm{M}\right)$ in the presence of $\mathrm{Hg}^{2+}$ ([filled square]: $1 \mu \mathrm{M}$; [filled circle]: $5 \mu \mathrm{M}$; [filled triangle]: $20 \mu \mathrm{M}$ ). (c) Ellipticity at $280 \mathrm{~nm}$ of CD spectra for $\mathrm{T}_{33}(1 \mu \mathrm{M})$ in solutions containing $5 \mathrm{mM} \mathrm{NH}_{4} \mathrm{OAc}$ and $20 \% \mathrm{MeOH}$ and [filled square] $) \mathrm{Hg}^{2+}(0-4 \mu \mathrm{M})$ or [filled triangle] $1 \mu \mathrm{M}$ EthBr and $\mathrm{Hg}^{2+}(0-4 \mu \mathrm{M})$. Other conditions were the same as those described in Figure 1.

molecules bonded to each $T_{33}$ strand. We obtained similar results using CD spectroscopy (Figure 5c). The values of the ellipticity of the solutions containing $\mathrm{T}_{33}$ $(1.0 \mu \mathrm{M})$ and EthBr $(1.0 \mu \mathrm{M})$ at $280 \mathrm{~nm}$ decreased upon increasing the $\mathrm{Hg}^{2+}$ concentration from 0 to $4.0 \mu \mathrm{M}$, mainly as a result of the formation of a hairpin-like DNA structures.

\section{Conclusions}

We have used ESI-MS and fluorescence and CD spectroscopy to explore the interactions among polyT strands, $\mathrm{EthBr}$, and $\mathrm{Hg}^{2+}$. Those results reveal that the formation of $\mathrm{T}_{33}-\mathrm{EthBr}-\mathrm{Hg}^{2+}$ complexes is dependent on the concentrations of $\mathrm{Hg}^{2+}$ and EthBr. The results also reveal that $\mathrm{Hg}^{2+}$ ions have greater affinity toward polyT strands than do other metal ions. Our results provide useful information for developing DNA-based sensors for the detection of heavy metal ions. For instance, the sensitivity of DNA-conjugated gold nanoparticles for the detection of $\mathrm{Hg}^{2+}$ may be enhanced in the presence of intercalators that can further stabilize the DNA structures $[28,29]$. Our approach also opens an avenue for studying the interactions of DNA with drugs in the presence and absence of metal ions, which may provide some potentially useful information for understanding drug activity and the role of metal ions on the biological function of DNA.

\section{Acknowledgments}

The authors acknowledge support for this study by the National Science Council of Taiwan under contract NSC 97-2627M-002-010. They thank L.-C. Yu and Y.-H. Tsai of Bruker Daltonics, Taiwan, for helpful discussions relating to the ESI-MS measurements.

\section{Appendix A Supplementary Material}

Supplementary material associated with this article may be found in the online version at doi:10.1016/ j.jasms.2009.06.009.

\section{References}

1. Zahir, F.; Rizwi, S. J.; Haq, S. K.; Khan, R. H. Low Dose Mercury Toxicity and Human Health. Environ. Toxicol. Pharmacol. 2005, 20, 351-360.

2. Miyake, Y.; Togashi, H.; Tashiro, M.; Yamaguchi, H.; Oda, S.; Kudo, M.; Tanaka, Y.; Kondo, Y.; Sawa, R.; Fujimoto, T.; Machinami, T.; Ono, A. Mercury-Mediated Formation of Thymine-Hg-Thymine Base Pairs in DNA Duplexes. J. Am. Chem. Soc. 2006, 128, 2172-2173.

3. Ono, A.; Togashi, H. Highly Selective Oligonucleotide-Based Sensor for Mercury(II) in Aqueous Solutions. Angew. Chem. Int. Ed. Engl. 2004, 43, 4300-4302.

4. Xue, X.; Wang, F.; Liu, X. One-Step, Room Temperature, Colorimetric Detection of Mercury $\left(\mathrm{Hg}^{2+}\right)$ Using DNA/Nanoparticle Conjugates. J. Am. Chem. Soc. 2008, 130, 3244-3245.

5. Liu, C.-W.; Hsieh, Y.-T.; Huang, C.-C.; Lin, Z.-H.; Chang, H.-T. Detection of Mercury(II) Based on $\mathrm{Hg}^{2+}$-DNA Complexes Inducing the Aggregation of Gold Nanoparticles. Chem. Commun. 2008, 2242-2244.

6. Chiang, C.-K.; Huang, C.-C.; Liu, C.-W.; Chang, H.-T. OligonucleotideBased Fluorescence Probe for Sensitive and Selective Detection of Mercury(II) in Aqueous Solution. Anal. Chem. 2008, 80, 3716-3721.

7. Rosu, F.; Gabelica, V.; Houssier, C.; Colson, P.; De Pauw, E. Triplex and Quadruplex DNA Structures Studied by Electrospray Mass Spectrometry. Rapid Commum. Mass Spectrom. 2002, 16, 1729-1736.

8. David, W. M.; Brodbelt, J.; Kerwin, S. M.; Thomas, P. W. Investigation of Quadruplex Oligonucleotide-Drug Interactions by Electrospray Ionization Mass Spectrometry. Anal. Chem. 2002, 74, 2029-2033.

9. Rosu, F.; De Pauw, E.; Guittat, L.; Alberti, P.; Lacroix, L.; Mailliet, P.; Riou, J.-F.; Mergny, J.-L. Selective Interaction of Ethidium Derivatives with Quadruplexes: An Equilibrium Dialysis and Electrospray Ionization Mass Spectrometry Analysis. Biochemistry 2003, 42, 10361-10371.

10. Li, H.; Yuan, G.; Du, D. Investigation of Formation, Recognition, Stabilization, and Conversion of Dimeric G-quadruplexes of HIV-1 Integrase Inhibitors by Electrospray Ionization Mass Spectrometry. J. Am. Soc. Mass Spectrom. 2008, 19, 550-559. 
11. Casagrande, V.; Alvino, A.; Bianco, A.; Ortaggi, G.; Franceschin, M. Study of Binding Affinity and Selectivity of Perylene and Coronene Derivatives Towards Duplex and Quadruplex DNA by ESI-MS. J. Mass Spectrom. 2009, 44, 530-540.

12. Pócsfalvi, G.; Landa, G. D.; Ferranti, P.; Ritieni, A.; Randazzo, G.; Malorni, A. Observation of Noncovalent Interactions Between Beauvericin and Oligonucleotides Using Electrospray Ionization Mass Spectrometry. Rapid Commum. Mass Spectrom. 1997, 11, 265-272.

13. Gabelica, V.; De Pauw, E.; Rosu, F. Interaction Between Antitumor Drugs and a Double-Stranded Oligonucleotide Studied by Electrospray Ionization Mass Spectrometry. J. Mass Spectrom. 1999, 34, 1328-1337.

14. Wan, K. X.; Shibue, T.; Gross, M. L. Noncovalent Complexes Between DNA-Binding Drugs and Double-Stranded Oligodeoxynucleotides: A Study by ESI Ion-Trap Mass Spectrometry. J. Am. Chem. Soc. 2000, 122, 300-307.

15. Rosu, F.; Gabelica, V.; Houssier, C.; De Pauw, E. Determination of Affinity, Stoichiometry, and Sequence Selectivity of Minor Groove Binder Complexes with Double-Stranded Oligodeoxynucleotides by Electrospray Ionization Mass Spectrometry. Nucleic Acids Res. 2002, 30 , e82.

16. Mazzitelli, C. L.; Chu, Y.; Reczek, J. J.; Iverson, B. L.; Brodbelt, J. S. Screening of Threading Bis-Intercalators Binding to Duplex DNA by Electrospray Ionization Tandem Mass Spectrometry. J. Am. Soc. Mass Spectrom. 2007, 18, 311-321.

17. Mazzitelli, C. L.; Brodbelt, J. S.; Kern, J. T.; Rodriguez, M.; Kerwin, S. M. Evaluation of Binding of Perylene Diimide and Benzannulated Perylene Diimide Ligands to DNA by Electrospray Ionization Mass Spectrometry. J. Am. Soc. Mass Spectrom. 2006, 17, 593-604.

18. Duhamel, J.; Kanyo, J.; Dinter-Gottlieb, G.; Lu, P. Fluorescence Emission of Ethidium Bromide Intercalated in Defined DNA Duplexes: Evaluation of Hydrodynamics Components. Biochemistry 1996, 35, 1668716697.

19. Wu, Q.; Cheng, X.; Hofstadler, S. A.; Smith, R. D. Specific MetalOligonucleotide Binding Studied by High Resolution Tandem Mass Spectrometry. J. Mass Spectrom. 1996, 31, 669-675.
20. Moon, S. T. M.; Schürch, S. Investigation of Metal-Oligonucleotide Complexes by Nanoelectrospray Tandem Mass Spectrometry in the Positive Mode. J. Am. Soc. Mass Spectrom. 2005, 16, 370-378.

21. Turner, K. B.; Monti, S. A.; Fabris, D. Like Polarity Ion/Ion Reactions Enable the Investigation of Specific Metal Interactions in Nucleic Acids and Their Noncovalent Assemblies. J. Am. Chem. Soc. 2008, 130, 1335313363.

22. Mazzitelli, C. L.; Rodriguez, M.; Kerwin, S. M.; Brodbelt, J. S. Evaluation of Metal-Mediated DNA Binding of Benzoxazole Ligands by Electrospray Ionization Mass Spectrometry. J. Am. Soc. Mass Spectrom. 2008, 19, 209-218.

23. Reyzer, M. L.; Brodbelt, J. S.; Kerwin, S. M.; Kumar, D. Evaluation of Complexation of Metal-Mediated DNA-Binding Drugs to Oligonucleotides via Electrospray Ionization Mass Spectrometry. Nucleic Acids Res. 2001, 29, e103.

24. Tseng, W.-L.; Hsieh, M.-M.; Wang, S.-J.; Chang, H.-T. Effect of Ionic Strength, $\mathrm{pH}$ and Polymer Concentration on the Separation of DNA Fragments in the Presence of Electroosmotic Flow. J. Chromatogr. A 2000, $894,219-230$

25. Tseng, W.-L.; Hsieh, M.-M.; Wang, S.-J.; Huang, C.-C.; Lin, Y.-C.; Chang P.-L.; Chang, H.-T. Analysis of Large-Volume DNA Markers and Polymerase Chain Reaction Products by Capillary Electrophoresis in the Presence of Electroosmotic Flow. I. Chromatogr. A 2001, 927, 179190.

26. Huang, M.-F.; Hsu, C.-E.; Tseng, W.-L.; Lin, Y.-C.; Chang, H.-T. Separation of dsDNA in the Presence of Electro-Osmotic Flow Under Discontinuous Conditions. Electrophoresis. 2001, 22, 2281-2290.

27. Rosu, F.; De Pauw, E.; Gabelica, V. Electrospray Mass Spectrometry to Study Drug-Nucleic Acids Interactions. Biochimie 2008, 90, 1074-1087.

28. Chen, S.-J.; Huang, Y.-F.; Huang, C.-C.; Lee, K. H.; Lin, Z.-H.; Chang, H.-T. Colorimetric Determination of Urinary Adenosine Using Aptamer-Modified Gold Nanoparticles. Biosens. Bioelectron. 2008, 23, 1749-1753.

29. Liu, C.-W.; Lin, Y.-W.; Huang, C.-C.; Chang, H.-T. Fluorescence Detection of Single-Nucleotide Polymorphisms using a Thymidine-Based Molecular Beacon. Biosens. Bioelectron. 2009, 24, 2541-2546. 